\title{
Publisher Correction: ER stress-induced mediator C/EBP homologous protein thwarts effector $T$ cell activity in tumors through T-bet repression
}

Yu Cao (1) ${ }^{1}$, Jimena Trillo-Tinoco ${ }^{1}$, Rosa A. Sierra ${ }^{1}$, Carmen Anadon ${ }^{1}$, Wenjie Dai ${ }^{1}$, Eslam Mohamed ${ }^{1}$, Ling Cen $^{2}$, Tara L. Costich ${ }^{1}$, Anthony Magliocco ${ }^{3}$, Douglas Marchion ${ }^{3}$, Richard Klar ${ }^{4}$, Sven Michel ${ }^{4}$, Frank Jaschinski ${ }^{4}$, Richard R. Reich", Shikhar Mehrotra ${ }^{6}$, Juan R. Cubillos-Ruiz 7,8 , David H. Munn', Jose R. Conejo-Garcia ${ }^{1}$ \& Paulo C. Rodriguez ${ }^{1}$

Correction to: Nature Communications https://doi.org/10.1038/s41467-019-09263-1, published online 20 March 2019.

The original version of this Article contained an error in Fig. 2. In Fig. 2d, the western blot panel relative to the human T cells (right) was an inadvertent copy of the western blot panel relative to the mouse T cells (left). This has been corrected in both the PDF and HTML versions of the Article.

Published online: 15 August 2019

(c) Open Access This article is licensed under a Creative Commons Attribution 4.0 International License, which permits use, sharing, adaptation, distribution and reproduction in any medium or format, as long as you give appropriate credit to the original author(s) and the source, provide a link to the Creative Commons license, and indicate if changes were made. The images or other third party material in this article are included in the article's Creative Commons license, unless indicated otherwise in a credit line to the material. If material is not included in the article's Creative Commons license and your intended use is not permitted by statutory regulation or exceeds the permitted use, you will need to obtain permission directly from the copyright holder. To view a copy of this license, visit http://creativecommons.org/licenses/by/4.0/.

(C) The Author(s) 2019

\footnotetext{
${ }^{1}$ Department of Immunology, H. Lee Moffitt Cancer Center \& Research Institute, Tampa, FL 33612, USA. ${ }^{2}$ Cancer Informatics Core, H. Lee Moffitt Cancer Center \& Research Institute, Tampa, FL 33612, USA. ${ }^{3}$ Department of Pathology, H. Lee Moffitt Cancer Center \& Research Institute, Tampa, FL 33612, USA. ${ }^{4}$ Secarna Pharmaceuticals GmbH \& Co. KG, 82152 Planegg/Martinsried, Germany. ${ }^{5}$ Biostatistics Program, H. Lee Moffitt Cancer Center \& Research Institute, Tampa, FL 33612, USA. ${ }^{6}$ Department of Surgery, Medical University of South Carolina, Charleston, SC 29425, USA. ${ }^{7}$ Department of Obstetrics and Gynecology, Weill Cornell Medicine, New York, NY 10065, USA. ${ }^{8}$ Sandra and Edward Meyer Cancer Center, Weill Cornell Medicine, New York, NY 10065, USA. ${ }^{9}$ Department of Pediatrics, Georgia Cancer Center, Augusta University, Augusta, GA 30912, USA. Correspondence and requests for materials should be addressed to P.C.R. (email: Paulo.Rodriguez@Moffitt.org)
} 